\title{
Patient Capital in the Age of Financialised Managerialism
}

\author{
Samuel Knafo and Sahil Jay Dutta
}

Pre-proofed version of an article published in Socio-Economic Review as part of a special issue on Patient capital edited by Richard Deeg, Iain Hardie and Sylvia Maxfield.

\begin{abstract}
This paper focuses on the history of financialised management and its connections to shareholder value which is often viewed as undermining patient strategies of investments. We argue that the rise of financialised management has in fact a long history that goes back to the conglomerate movement in 1960s America. As we show, the conglomerates pioneered the use of financial markets as a baseline for strategy, and the emphasis on financial transactions as an engine for growth. They developed key techniques - high leverage, share-price maximisation, accounting manipulation - that later came to be associated with managerial strategies of the shareholder value era. This legacy has important implications for how we think about patient capital. It challenges the idea that patient capital consists foremost in shielding non-financial companies from capital markets and highlights the central role of management too often neglected in these debates.
\end{abstract}

Keywords: financialisation, corporate governance, shareholders, economic history, corporate finance, USA

JEL classification: P16 political economy, N22 economic history, G34 Corporate Finance and Governance

\section{Introduction}

'Modern capital markets rarely give the impression of valuing the long term; they delight in profits being distributed rather than reinvested.' - Andy Haldane, chief economist at the Bank of England (2015)

Since the 2008 financial crisis, regulators, politicians and academics have talked up the potential of 'patient capital' to nurture a sustained economic recovery (Kay, 2011; Wehinger, 2011; Bailey and Godsall, 2013). Their interest in patience stems from an unease regarding the pressures for immediate returns placed by shareholders upon non-financial companies (NFCs). Many believe, like Haldane, that financial markets do not always value the long term and worry that exposure to the imperatives of financial markets contort NFC strategies and instil short-termist and speculative behaviour that undermine labour, productive investment and economic stability.

This paper challenges the idea that impatience initially emanated from financial markets. The familiar story of the financialisation of the firm (Lazonick and O'Sullivan, 2000; Duménil and Lévy, 2004; Ho, 2009) lends too much weight to the capacity of shareholders to dictate managerial norms and often misunderstands the source of 'impatient' strategies of accumulation by interpreting them as the structural product of increasingly liberalised capital markets. By contrast, we argue that the rise of NFC impatience has a more distinct historical origin, which can be traced back to the specific managerial innovations of a group of NFCs: the 1960s conglomerates. As we will show, these firms pioneered strategies of corporate growth that relied foremost on capitalising on financial markets and set the foundations for a new form of management that profoundly shook the American corporate establishment.

Pointing to the links between financialisation and corporate strategy highlights the agency of 
managerial teams using financial markets as engines of corporate growth and empowerment. This is important for as Deeg and Hardie point out, the common emphasis on protecting NFC managers from volatile equity markets risks 'pushing the analysis of what patient capital is too far in the direction of a focus on managerial autonomy from shareholders' (2016, this issue). Tracing the pivotal role of managers in the financialisation of the firm leads us to emphasise the need to cast patient capital more explicitly as a social relation. For in an age of abundant credit, the issue of patient capital cannot be, and was not initially, posed simply as a concern regarding lenders or impatient shareholders/owners. What managers did with their capital has often proven more significant. In fact, we argue that the problem of impatience stems more from the resources capital markets provide corporations, than it does from an actual 'lack of patient capital'.

In making this argument, we focus on the early financialisation of the firm from the late 1960s up to the mid 1980 s by contrast to a literature that usually takes the late 1980s-1990s 'shareholder era' as a baseline for discussions about short-termism and patient capital (Soener, 2015; Van der Zwan, 2014). However, we do not provide here a 'history' of the financialisation of the firm. Rather this is an exercise in conceptualisation. It builds on a well-established history to make a case for re-thinking the problem of patient capital. By revisiting historical literatures that are too often neglected in debates on patient capital, we seek to re-align our understanding of the 'problem of impatience' with established facts which, if taken into account, profoundly change how we conceptualise patient capital and the broader context of the financialisation of NFCs. In that respect, this is an exercise in theorisation, a practice of radical historicism aimed at re-calibrating our conceptual framework (Knafo, 2013).

We undertake this work of conceptualisation in four steps. First, we discuss the literature on patient capital with an emphasis on the early context of its emergence to outline what is distinctive about the way it casts the relationship between finance and production. As we show, this concept largely took form in the 1980s as part of a response of the corporate establishment to the challenges set by financialised managerial teams that leveraged their operations through financial markets to rapidly capture other firms. The result was a concept of patient capital that placed the emphasis on the time horizon of investors, who were seen to be complicit in this process, rather than the more traditional concerns with financial support or industrial leadership, which had animated previous discussions about the role of finance in production. The second section focuses on the origins of the financialisation of the firm to trace the corporate strategies that gave rise to the debate on patient capital in the 1980s. While much of the comparative political economy literature reads the problem of short termism as a diffuse institutional or cultural problem, pointing to various factors which inflect the time horizon of managers and which are taken as representative of a broader structural context (Laverty, 1996, Jackson and Petraki, 2011), we view it as a socio historical problem with a distinct lineage that must be traced to grasp the specificity of its corporate practices and the politics to which it gave rise. As we argue, it was the development of a new style of management geared towards taking positions on financial markets in order to capitalise on them which marks the real breakthrough. Having emphasised the managerial origins of impatience, the third section looks at the ways in which financiers became involved in financialised management and the pivotal role of investment banks in pushing financialised management to a new level. Finally, the last section reassesses the role of shareholders in this transformation. We argue that the early financialisation of NFCs suggests that it was shareholders who were later brought into line with this new type of financialised management, rather than the other way round. This will lead us to conclude that the problem of impatience is fundamentally a managerial problem which is connected to the opportunities financial markets provide for corporate strategy.

\section{The origins of patient capital}

The term 'patient capital' was barely used until it found political salience in 1980s America. When it first emerged patient capital referred to a much broader set of issues than NFC exposure to 
financial markets. It was first debated in 1983 when Democrat congressman Stan Lundine sponsored the creation of a National Industrial Development Bank. The bank, he said, would reward 'an industry that takes high risks and invests in productive capacity' with 'capital on better terms so called "patient capital"' (1983, p. 20). At the time, policymakers and industrialists in America were especially worried about international competition from Japan and there was interest in reviving the New Deal idea of a national development bank. Introducing his proposed legislation, Lundine wrote: "In today's context we are simply not able to generate the kind of "patient capital" needed to foster innovative, new, and emerging enterprises' (ibid.). This concern was a continuation of Lundine's interest in the institutions of trust-based capitalism. Before entering Congress Lundine had found recognition as a progressive Mayor of Jamestown, New York, trying to develop Germanstyle labour/management councils. He hoped that through a national development bank, financiers would take responsibility to 'lead' industry and finance the upscaling of America's industrial base with the support of the state if necessary.

That same year John Zysman published Government, Markets and Growth which became the touchstone for much of the academic work on comparative finance (1983). He was originally interested in the possibilities for building state capacity for exerting 'industrial leadership': the ability to 'consciously influence and guide the pattern of investment, competition, and exchange between sectors or the industrial organization of particular industries' (Zysman, 1977, p. 848). It was clear to Zysman that power was the issue at stake when it came to patient investment. More than simply lending money on a long-term horizon, Zysman was concerned with disciplining corporate management into adopting such strategies. This was a task he felt American market finance was ill equipped to carry out, not because it would expose NFCs to an irresistible volatility, but because the 'decentralised financial system, with a strong securities market, contributed to a concentration of power and decision making in the corporation itself' (Zysman, 1983, p. 269). Focussing on the state and the necessity of leadership, Zysman argued that the lack of patient capital meant that America was missing an agent capable of forcing NFCs into the kind of longterm strategies that would allow them to compete globally.

But 1983 was also a big turning point for corporate governance with the beginning of what Martin Lipton, the famous corporate lawyer, would later describe derogatively' as a wave of 'bust up takeovers' (Bruck, 1989: 209). Fuelled by the explosion of leveraged buyouts (LBOs) from that year onwards, the mid 1980s would witness the arrival of new 'takeover entrepreneurs' who rocked corporate America. It was an assault that rapidly altered the significance of the term patient capital away from that found in the interventions of Lundine and Zysman. As the corporate establishment mobilised to lobby for legislation restricting takeovers, the business press took hold of the idea that patient capital was needed to meet the competitive pressures of Japan but quickly assigned new political valences to it, bringing it close to what we now associate with the term.

The concern with disciplining management was quickly displaced in favour of an emphasis on the importance of investor support as financial markets were now identified as driving impatience. In this context, patience no longer meant coordinated competition and industrial leadership, as in the classic discussions of industrialisation (Gerschenkron, 1962) which had informed the work of Zysman. It became increasingly a matter of protecting the industrial base from rapacious investors cashing in on the hard-earned assets of corporations. As corporate managers were simply taken by the speed with which the raiders were moving, a premium was placed on time as they struggled to find ways to slow down and temper volatile investors caught in the movement. Donald Frey, a former Ford executive, thus wrote in Fortune magazine in 1986 that the US 'needed patient investors' to compete with the MITI-system Japanese car manufacturers. It was a similar point that Elmer Johnson, a former manager at General Motors, articulated in the pages of the Harvard Business Review pointing to the emergence of professional investors who mobilised with devastating consequences through the LBO boom and made financial market imperatives articulated through the threat of 'exit' too powerful and too blunt. As a result 'managers ha[d] little choice but to sub-ordinate long-term goals to an all-out effort to report record earnings for each new quarter and adopt effective antitakeover measures: poison pills, ingenious charter 
provisions, and leveraging the balance sheet' (Johnson 1990, p. 52). While the business press thus argued that 'finance' did have in fact the 'financial power' which Zysman had said was missing, it was no portent for industrial leadership. From this perspective, it had become a destructive force imposing its own short term agenda.

Concerns with short termism have since been repeatedly employed to articulate managerial interests in relation to shareholders. Regulators and the press have generally followed this script. As Roe points out, 'over the years, the chairs of the Securities and Exchange Commission, Congress, business analysts, and the business media have regularly excoriated trading markets as perniciously shortening corporate time horizons' and used this critique to justify 'corporate law rules insulating boards from markets' (2013, p. 979). This has led to a sustained campaign to remind institutional funds in particular of the need for them to commit to long term investments (Aspen Institute, 2009).

Despite its political saliency, however, the term patient capital did not really enter the academic lexicon until the 1990s, and flourished only after the 2008 financial crisis. By that point, the framing of the question of patient capital had been largely etched along the lines set by the business press. It was a narrative which continued to place the blame primarily on shareholders for setting the terms of management, even if managers were also criticised for giving in too easily to these imperatives in order to maximise their own personal rewards (Aspara et al. 2014). As Jackson and Petraki note, underpinning this view was the assumption that impatience was counterproductive from the perspective of the firm (2011, p. 201), with shareholders and managers seen to be depleting the resources of corporations. This explains why the literature was prone to emphasise rent seeking behaviour, rather than corporate strategy. It was a perverse outcome that scholars were often tempted to pin down on structural constraints set by the liberalisation of capital markets. As a result, many came to equate the erosion of patience with growing market imperatives, or more specifically with the exposure of corporations to capital markets (Horn, 2011, p. 39).

It is our contention that this reading does not square well with the history of American corporate governance. It is widely recognised that the development of increasingly liquid capital markets in the 1920s and 1960s empowered managers in the US, rather than undermined them. The ability of corporations to raise large levels of debts and the new channels opened for segments of the economy previously barred from capital markets (e.g. with junk bonds) suggest that market finance does not necessarily constrain management but also provides new opportunities. In other words, it does not impact management in any linear or structural way. For this reason, we move away from a structural account that focuses on the pressures of capital markets and turn to the agency of NFC managers to provide a different perspective on the problem of impatience.

\section{The rise of financialised management}

In the Transformation of Corporate Control, Neil Fligstein (1990) makes a strong case for examining the early roots of the financialisation of NFCs in the late 1950s and 1960s. Of particular importance were the so-called conglomerates, which emerged during this period. The term refers to an assortment of firms mostly built by outsiders with little previous corporate experience and limited ties to the corporate establishment (Sobel, 1984). Their rise took place as part of a broader movement of American corporations towards diversification, but what marked them out was the way in which they pursued diversification through financial means. Its leading pioneers, firms such as ITT, LTV, Litton and Gulf \& Western, managed to grow at a very rapid pace on the basis of sustained acquisitions and financial dealings (Berg, 1969, p. 113). As Fligstein points out, many of the practices of corporate reorganisation which later became associated with financialisation (aggressive mergers, divestitures, LBOs, leveraging, stock repurchasing) were developed and perfected during this period as these firms innovated in order to sustain and expand their operations (Fligstein and Markovitz, 1993, p. 193).

While Fligstein flags the pioneering role of the conglomerates, however, he conceptualises their activities through the lens of his financial concept of control, an underspecified notion which characterises this shift to finance in very general terms as a move towards a practice of management 
based on financial considerations and expertise. According to this view, the corporation was reconceptualised as a portfolio of assets with corporate managers willing to buy and sell their way in and out of product lines depending on their respective performance. But this view leads Fligstein to emphasise operational matters rather than the forays on capital markets which are mostly treated as incidental to portfolio management. It is no coincidence then if he barely discusses capital markets in his analysis of the financial concept of control and ventures only few lines about the financial expedients of conglomerates (Fligstein, 1990, pp. 226-258).

By contrast, we propose the notion of financialised management to mark out the way conglomerates pioneered strategies predicated on systematically capitalising on financial markets. What marked out financialised management was not simply the outlook of managers imposing a financial bottom line on the multidivisional firm, but a focus on using capital markets as engines of corporate growth. The strategic orientation of conglomerates became increasingly focused on generating profits through financial transactions, rather than improved operational management (Hyman, 2012, p. 198). The most financialised conglomerates succeeded for a while in feeding off a virtuous cycle by turning their performances on financial markets (e.g. high share prices) into tangible resources they could use to take new positions on these markets. As they became more active on capital markets in the process of conducting mergers, they increasingly used those markets as means for empowerment. Having come more or less 'out of nowhere' as Sobel points out, they compensated for their limitations by systematically tapping financial market. This is why, contra Fligstein who insists on the continuity between the conglomerates and the rest of the corporate establishment, we emphasise their contrasting practices. As Goolrick notes, many commented at the time on the threat these conglomerates represented for establishment-type companies (1978, pp. 78-79). As it would later be the case, this crystallised a vital political fault line which played a central role in the financialisation of the firm.

The shift to financialised management comprised a series of transformations that would have a lasting impact on the corporate landscape:

a) Acquisitions: Acquisitions were the pivotal component of financialised management. Some of the conglomerates joined the ranks of the biggest industrial concerns in America through such acquisitions. Most of the big conglomerates made each more than fifty acquisitions in the decade leading up to 1968 (Berg, 1969, p. 113); acquisitions which were usually made more with an eye to financial markets than their productive synergies. Conglomerates did not have a particularly good track record in terms of production or entrepreneurial acumen in creating synergies among the various firms and divisions they owned. Rather they presented themselves as risk managers who were more efficient than traditional corporations because of their focus on investing capital 'wherever it worked most efficiently' (Hyman, 2012, p. 199). According to Norman Berg's estimates, their management structures were often very thin, amounting at times to about a tenth of the managerial structures of more established firms of the same size (Berg, 1969, p. 114). Some conglomerators saw themselves as 'managers of managers' and most were focused on finding ways to motivate managers of their divisions, sometimes through the issue of stock options. They were known for their limited commitment to Research and Development and their casual approach to organisational matters, at least from the perspective of creating effective internal synergies. In short, their success was usually predicated more on financial dealings than internal operations.

Their acquisitions were usually aimed at increasing the cash inflow, often at the cost of long-term liabilities. In this respect, financialised management should not be conflated with the portfolio approach, commonly associated with the corporate world of the 1970s and often used as baseline for thinking about the early financialisation of the firm (see Zorn et al, 2004). Portfolio management was born out of the strategic revolution in management consulting that occurred in the 1960s and which focused on the performance of divisions which were here treated as assets. While the focus was set on the financial bottom line, the key vectors to determine the potential value of a firm's assets (or divisions) were defined in terms of economies of scale and market shares (Kiechel III, 2010). By contrast, financialised management treated assets in financial terms based on market 
value (not simply according to financial indicators concerned with the performance of these divisions). These assets were to be sold or restructured so as to produce value in the form of better share prices or increased cash flow. The objective was often the capture of assets through the stock market (cash reserves, commodity inventories for example in oil, or divisions/subsidiaries to be sold) rather than operational considerations. For example, conglomerates became interested in insurance companies (and banks) towards the last years of the 1960s so as to get their hands on liquidities they could re-invest to finance their other operations, not because insurance was an up and coming product line (Brooks, 1973).

Their ability to capitalise on stock markets was often vital to the conglomerates' rapid growth as they parlayed mergers into rising share prices to further tap financial markets for capital. This explains that already in the 1960s, conglomerates put much effort into appearing attractive to shareholders long before the turn to shareholder value in the 1980s. One of the most successful in this respect was Litton industry. Its manager, Charles Thornton, pursued the acquisition of high profile firms in new technology sectors (though he himself did little to foster R\&D) (Sobel, 1984). These enabled him to build a plausible rational for diversified acquisitions which would sit well with Wall Street. Thornton's ability to play up to Wall Street through projecting promising technologies meant that he was able to maintain a high share price even when Litton ventured beyond electronics in the late 1950s, and began to purchase bigger but often struggling firms that it failed to prop up. Litton's results, in terms of earnings, were increasingly disappointing but this did not undermine its ability to further tap financial markets. It was thus able to sustain the pace of acquisitions through the 1960s partly through the momentum of the stock market.

This focus on acquisitions helps explain why the conglomerates came to dominate the wave of takeovers in the late 1960s, accounting for about $80 \%$ of mergers according to the Federal Trade Commission board (in Gaughan, 2011, p. 44). Firms such as ITT and Gulf and Western captured more than twenty firms each in 1968 alone (Sobel, 1984, p. 118). Gulf Western went, in fact, a step further as it repeatedly profited from failed acquisitions when the rise in the price of the shares it targeted allowed the firm to sell back a minority position initially acquired at a lower price for great profits. A 'failed' bid for the much larger Sinclair Oil in 1968, for example, netted a $\$ 24.2$ million profit (Sobel, 1984: 119). It was the type of practice which would contribute to the antagonism directed against the conglomerates.

b) Financialised restructuring: The idea that the nominal value of a company was often lower than the potential value of its components was central to much of the restructuring conducted under financialised management. Divestments of divisions and subsidiaries became a key means for financing further deals, with conglomerates often being reorganised with an eye to further capitalise on financial markets. This could mean pursuing policies that would be well-received on the stock market, but also strategies to multiply the channels by which one could tap financial markets. The use of subsidiaries which could issue their own shares or debt was particularly important in this respect as it would also be in the 1980s (Prechel 1997; Kreier 2005, p. 8).

Perhaps the most spectacular case of a financialised conglomerate was LTV, which managed to vault from the 204th to the 14th largest industrial concern in the US between 1965 and 1969 purely on the back of its ruthless deal-making (Sobel, 1984, p. 78). Its manager, James Ling, became renowned for his ability to use the momentum imparted by capital markets in order to capture firms. Ling was a pioneer in using debt-financed acquisitions that foreshadowed LBOs, and share buybacks to bolster the position of LTV on financial markets. For Ling, going public by creating new subsidiaries became a means not only to raise money but also a strategy for making his collection of assets visible on capital markets so as to create enthusiasm and find new ways to capitalise on financial markets. He preyed particularly on complex multidivisional firms which offered great opportunities for selling assets or reorganising them so as to increase leverage and exposure on financial markets (Sobel, 1984, p. 93). 
c) Leveraging: This financialised management came to be marked by the extent to which conglomerates became leveraged. For while their success may have hinged on their continued ability to capitalise on the stock market, it was the muscle provided by debt financing which would be vital to their success. Indeed, the ability to avoid diluting Earning per Shares (EPS) and corporate control meant that considerable resources went into stock repurchases or creative forms of debt/equity hybrids (Greiman, 1970, p. 712). The result was a strong reliance on bonds with warrants attached to them which would provide the option for investors to potentially benefit from rising share price but without unduly diluting EPS by limiting the initial issue of shares. As it would regularly be the case during the shareholder era of the 1990s, activities in the market for corporate control may have fuelled a spectacular growth of the stock market, but the striking feature of corporate finance was the heavy reliance on debt. Hence, during the height of the conglomerate era (1965-1970), the overall corporate debt to equity ratio grew from 0.48 to 0.72 (Lazonick and O'Sullivan, 1997, p. 17). Financialised conglomerates thus learned to live with great debt ratios as financial considerations to do with balancing out cash flows took a primacy over other operational matters.

Particularly important to this era was the emergence of the cash tender offer, by which a willing acquirer would make a public offer to buy shares with cash. It was a more decisive way to gain control than past strategies, which revolved around proxy fights or share swaps, but they required much more capital (Armour and Cheffins, 2014). By 1965, 70 per cent of all bids were made through cash tenders (Baskin \& Miranti, 1997, p. 286) and managing such a feat required growing capacities to raise money in the form of debt. The ability to leverage was not only reflected by the rapid increases in the size of the target for acquisitions, but more importantly by the fact that it became common to see smaller firms capture larger targets, something almost unheard of in earlier waves of mergers and acquisitions (Gaughan, 2011, p. 44) and a direct reason again for why financialised management was perceived as a direct threat to the corporate establishment.

d) Accounting manipulations: As the gains from financial dealings became increasingly attractive, financial considerations took a life of their own with executives prioritising them over more traditional concerns with productivity and organisational synergies (Zorn, 2004). In doing so, rapid growth became hard-wired into financial operations, which meant that financialised management required the continual development of new capacities for capitalising on financial markets, even if these proved difficult to sustain, as was often the case. This led to the desperate efforts by conglomerate managers to continue riding speculative waves on financial markets, which often generated distinct imperatives of their own. Executives often felt compelled to focus increasingly on financial dealings, simply to maintain the thrust imparted by their financial practices of management. Acquisitions grew dramatically in size and frequency. As expectations on financial markets were set and financial commitments made, especially in the form of growing debt burdens, executives had little choice but to further the process of financialisation and seek new ways to capitalise further on capital markets.

This may help explain why financialised management seemed so often to entail accounting manipulations. Systematic manipulations were a recurrent theme in the late 1960s, much as they would be later in the 1990s. This was not simply a symptom of corporate greed but was tied to the changing nature of managerial strategies. For navigating financial markets came to depend increasingly on the ways in which a firm could represent itself on capital markets. The conglomerates placed great emphasis on wooing shareholders and pushing up share values through manipulating figures such as EPS. In doing so, conglomerates often looked for firms with lower price-to-earnings ratios, so that the very act of combining with these firms would increase their EPS. Teledyne, for example, was repeatedly able to post annual increases in EPS of $90 \%$, solely through mergers that gave the impression of efficient management, without actually making concrete changes to the actual operations of the divisions (Madrick, 1987, p. 64). To sustain this momentum, conglomerates also relied heavily on the accounting method of pooling, rather than what was seen by regulators as the more logical purchasing method. This method inflated earnings 
by registering only the cost of a merger in the form of the market value of the assets of a firm, which was often lower than the actual price paid for when initially acquired (Grieman, 1970). As a result, once more, earnings were systematically inflated in ways which did not reflect the financial commitments made. But this also involved exploiting new opportunities that were offered by the process of acquisition itself either for manipulating accounting through write-offs and deferred costs or exploiting tax reductions and loopholes (Briloff, 1970).

These four features would become characteristic of a new form of management that profoundly rocked the corporate establishment. That something radically new was afoot, was clearly appreciated by regulators who saw these activities as significant threat and their concerns prefigured those about patient capital which took form a decade later. Regulators, often supported by key figures of the financial and corporate establishment, bemoaned what they saw as a strategy of smoke and mirrors that was designed to quickly cash in through financial dealings at the expense of proper investments in real growth (Hyman, 2012: 201). The Federal Trade Commission and the SEC in the late 1960s became antagonistic to what they saw as the conglomerates' overemphasis on financial indicators as the baseline to assess return on investment, and the way conglomerates systematically relied on financial markets to leverage their corporate activities. This view was echoed by a congressional subcommittee which concluded, in its 1970 report on the biggest conglomerates (LTV, G\&W, ITT, Litton, and National General), that 'financial considerations and not productivity goals were dominant motivating forces in the postwar merger movement' (in Raw, 1977 , p. 225). This accounts for why Nixon's administration, seen to be close to the corporate establishment, would in fact seek to clamp down on the practices of conglomerates.

Although the history of the conglomerates has been well-established and their financial orientation partly recognised, they continue to be mostly ignored in discussions of financialisation of the corporations. The literature on shareholder value or on short-termism never mentions these conglomerates, nor do these firms register in debates about patient capital. The reason is largely that the collapse of financial markets in the early 1970s, and the downturn of the stock market that began in 1969, proved disastrous for the conglomerates and their style of management. It took away the very motor that propelled them, and thus led to their decline. Yet this counterargument fails to recognise the important connections developed between the conglomerates and the financial world. These would play a vital role in carrying over the innovations of the conglomerates and pushing their brand of financialised management to a new level in the 1980s.

\section{Wall Street and financialised management}

Instead of focusing on the agency of conglomerates, the literature has usually interpreted, if not normalised, the rise of financialised norms of management as a direct consequence of the economic and structural crisis of the 1970s. A problem, however, for those who think that capital simply took the high road of finance in response to the difficulties of the 1970s, is that this crisis was not only one of American industry; it was also one for financialised management. As the conglomerates had shown, the financialisation of the firm required a greater level of institutional support to be viable. It was one that Wall Street would ultimately provide, but there was nothing straightforward about this. As we argue here, financialised management posed significant problems for finance, forcing banks to innovate and transform often at the cost of great internal conflicts. It was the agency of specific banks that would finally make it possible for finance to chime in with financialised management.

Pivotal here were the investment banks which served as the crucial linchpin for financialised management after the decline of the conglomerates. These banks first got involved with financialised management through their role in the conglomerate-dominated expansion of the takeover market in the mid 1960s. It is important to point out that before the 1970s, investment banks did not have departments specialised in mergers and acquisitions, a service they initially saw as secondary to their main business of underwriting (Chandler, 1990, p. 624). But this changed as 
numerous banks became involved with conglomerates in the 1960s, helping them identify targets for acquisitions and working on the mechanics of takeovers (Sobel, 1984). Particularly important here were banks like Lazard Frères, where the influential Felix Rohatyn was instrumental to the operations of Henry Geneen's ITT, the biggest of the conglomerates. Lehman Brothers played a significant role financing Litton and LTV, while Chase Manhattan, a commercial bank, had close ties to Gulf Western (Sobel, 1984).

It was not inevitable, however, that some investment banks converged with the practices of financialised management. To begin with, the techniques they subsequently developed did not come from their own initiatives but rather were driven initially by the managerial demands of the conglomerates (Chernow, 1990). There was great reluctance at first within the banking community to become involved in these activities. Just as the corporate establishment they served, the underwriting experts who dominated investment banks were opposed to the activities of the conglomerates. This was because providing information about potential targets and supporting the wave of takeovers threatened to undermine the trust that underwriters had built with corporations, something the underwriters saw as vital for securing future contracts.

Conflicts within banks raged for more than a decade with most investment banks only letting go of their main advisory role in the late 1970s and early 1980s once blue chip corporations, their traditional clients, began to systematically take the route of disintermediation (Chernow, 1990). By that point, the M\&A teams were increasingly mainstreaming mergers and acquisitions, as big corporations sought to take advantages of the opportunities for profitable acquisitions. Inflation was then increasing the value of the assets owned by firms while a stagnant stock market was making these firms increasingly cheap to purchase. In this context, investment banks became increasingly proactive in proposing mergers and gradually refined the mechanics of takeovers, which facilitated hostile ones (Cole, 2008). But in the process they moved away from the template set by the conglomerates and came closer to the classic portfolio approach to management. During the 1970s, it was dominant firms that grew through mergers and their acquisitions were financed from large cash reserves with an eye very much on growth, rather than divestment (Madrick, 1987). This meant that there was less need to align management on financial markets, because these dominant firms were not relying on these markets to leverage their activities in the way that the conglomerates had done before.

It was one investment bank which actually pushed the conglomerate legacy of financialised management into the 1980s: Drexel Burnham and Lambert. It became renowned for its use of below investment grade bonds, or 'junk bonds', which it exploited to finance corporate raiders and LBO firms. This set the foundations for a series of acquisitions in the 1980s as part of a broader strategy that owed much to the practices of conglomerates, although with shorter horizons and more drastic methods. Firms were targeted on the basis of their low value on markets with an eye to rapidly restructuring them and increasing their value. In the process, there was great leveraging, usually paid for by divesting assets of the corporations targeted or saddling the latter with the debt incurred in the takeover.

Michael Milken was the force behind Drexel Burnham Lambert and the architect of the development of a secondary market for junk bonds in the 1970s. It is very significant, even if rarely mentioned, that he succeeded partly through his close collaboration with conglomerators such as Meshulam Riklis, Saul Steinberg and Carl Lindner, who had been important players in the 1960s. Milken's portfolio of junk bonds was in fact largely made of debts previously issued by these conglomerates (Bruck, 1989, p. 35). By the 1970s, conglomerators were struggling to support the value and credibility of their bonds because of a lack of demand and trust. As Benjamin Stern documents, these conglomerators were able through their association with Milken to re-establish a secondary market for their paper, often initially by buying each others bonds, in order to prop up and legitimate their respective issues (Stern, 1992, p. 48). The workings of this inner circle would become a defining feature of Milken's operations that enabled a rapid placement for securities by using his collaborators to effectively buy one another's bonds (Zey, 1993). With time, the network grew, providing broader scope for the circulation of this paper and making it increasingly possible 
to finance vast operations. As Milken's practices matured and his network for placement of junk bonds consolidated, he was able to issue himself junk bonds to stunning effects, and took the corporate world by storm through his ability to raise large sums rapidly, a key advantage for capturing firms (Kaufman and Englander, 1993). Considering his long association with conglomerators, it is no surprise that Milken used his financial machinery to support a rapidly growing network of corporate raiders who would use this to further deploy the strategies of financialised management.

At the forefront of this revolution were the LBO firms which refined this peculiar fusion of managerial practice and financial strategic considerations. The founding partners of KKR, the premier LBO firm, cut their teeth organising LBOs partly as a service to managers and devoted a significant part of their early work to help conglomerates divest themselves of assets (Bartlett, 1991 , p. 45). Increasingly, practices of LBO firms such as KKR would come to re-deploy the practices of financialised conglomerates in leveraging themselves to buy up undervalued firms whose assets could be restructured to improve their value, and sold off. In the new financial context, taking these assets private in the form of an LBO often proved the best way to carry out this type of financialised management. For the centrifugal forces of financialisation made it increasingly difficult to accumulate assets because of the difficulty of translating a broad range of assets into a nominal value sufficiently high to deter predators (Davis et al., 1994).

The turning point for the take-off of the LBOs was 1983, a date we already singled out as pivotal to the discussion over patient capital. That year Milken decided to put his machinery to use for funding LBO takeovers. Having been worth \$11 billion in the period going from 1977 to 1983, the value of LBO takeovers exploded to \$233 billion between 1984 and 1989 (Stearns and Allan, 1996, p. 706). This support of junk bond financing played most notably a vital role in pushing KKR to a new level, as reflected with their then unprecedented bid for Beatrice. More importantly, this financing propped a new wave of raiders closely tied to Milken who accentuated the logic of divestment of financialised management. This wave of corporate raiders essentially redeployed many of the ideas which had been developed by conglomerates. The great difference was the financial resources that were now available. Offering high interest rates made it easy to raise money but it also meant that raiders needed ruthless strategies to cash in on the acquisitions to cover for the costs. As the competitive edge of financialised management was pushed further with securitisation, the initiative was given to those who focused on divestments and cashing in, rather than those piling up assets.

In this way, the innovations of investment banks made corporate contests more ruthless and intensified the problem of impatience. It is thus no coincidence if the term of patient capital would take on its new features during the mid-1980s precisely when financialised management was unleashed on a new level. Already on the eve of the 1970s, government officials and most of the corporate establishment had been appalled with the short term horizons of conglomerates that paid no respect to tradition or broader sets of stakeholders. But by 1985, managers and politicians were shocked at the sight of small firms and raiders capturing great pillars of corporate America and stripping their assets. The concern led policymakers to attempt to pass new laws aimed at restricting the market for corporate control. By the spring of 1985, more than 30 regulations were tabled in Congress to stop the wave of takeovers (Bruck, 1989: 209) and the courts were repeatedly calledupon to protect corporations from being ransacked for their assets. There was real anxiety within the corporate establishment at the sight of a wave of takeovers dilapidating the industrial landscape. In this context, shareholder value took form as the main response of the corporate establishment to the threat posed by financialised management.

\section{4- Shareholder value and the financial turn of established corporations}

As we have argued, the main agents of the financialisation of the firm were managerial teams which developed tools to systematically capitalise on financial markets and the specific 
investment banks which came to support them. They shaped the early financialisation of the firm through their innovations. Integral to our argument is the claim that there is, by contrast, little historical evidence to trace back such changes to the agency of shareholders. Shareholder activism generally emerged quite late in the process of the financialisation of the firm and when it did, it was not aimed at raising corporate performance per se, but rather to 'get in on the action' and benefit from the managerial contests which were multiplying around acquisitions.

However, one may still assume that the conglomerates, and Milken's financial raiders, played into the hands of shareholders and, more generally, finance. It is true that the attempts by financialised managerial teams to enrol shareholders in the context of corporate contests over acquisitions certainly helped politicise corporate governance, and increase the visibility of shareholder concerns. Yet shareholders did not have it their way. Studies of shareholder activism show that shareholders have had, at best, mixed results in terms of increasing value delivered to investors (Froud et al., 2006) and that upholding 'shareholder value' has often resulted in disappointing outcomes for investors (O'Sullivan, 2000; Gillan and Starks, 2007). This does not mean that managers simply dictated terms for financialised management, but that their practices and strategies cannot be read directly off their surroundings. Instead, managers played a pivotal role in translating the opportunities and constraints of their environment into distinct practices of management, which can only be captured with a focus on their agency.

Interestingly, there is a long history in the United States of managers talking up their commitment to shareholders. It precedes the so-called shareholder revolution, and is in no way correlated with acting in the interest of shareholders. This discourse, in fact, took form initially with the separation of managerialism from ownership in the 1920s which is usually seen as the source of the very problem that the shareholder revolution was meant to address. As Julia Ott's (2011) shows, the discourse of managers serving shareholders was tied to the democratisation of shareholding and reflected an attempt to reassure small investors who were getting involved in the stock market. Wooing these small shareholders would be in turn a decisive reason behind the ability of corporate managers to gain autonomy from blockholder owners or the attempts of actual owners to raise money without losing control. The idea of serving shareholder interest became a central motif of corporate governance in the US and was modulated in various ways throughout the postwar era. Managers appealed to various strands of this 'shareholder' ideology, with shareholders being already cajoled by managerial teams in the context of takeovers or managerial contests in the 1950s (Sobel, 1993, p. 15).

This brings us back to the key political fault-line we have emphasised in this article. For the discourses and templates of shareholder value were not simply cultural artefacts that served to set new priorities in the context of rising market fundamentalism. They took form as more established corporations sought to come to terms with the thrust of financialised management. At stake was the question of what, from financialised management, could be translated into the practices of established corporations. Two of the main architects of shareholder value, Alfred Rappaport and Joel Stern, began fleshing out their ideas in the late 1960s and 1970s, initially on the back of a critique of conglomerates and their use of EPS, which they criticised their arbitrary manipulations rather than effective management. Both Stern and Rappaport were motivated to build a different baseline for organising a practice of management more attuned to capacities for capitalising on financial markets. While they framed their ideas around the notion of shareholder value, their concerns were managerial. Stern had been a management consultant since the late 1960s and worked to draw out the implications of the work of financial theorists such as Modigliani and Miller for corporate governance (Stern and Willets, 2014). Rappaport meanwhile fleshed his own conception of shareholder value initially as a means for managers to assess profitable mergers from a different analytical standpoint than the more common portfolio approach that dominated the corporate establishment (Rappaport, 1979). From the beginning, these early templates of shareholder value were conceived as tools of management, with references to shareholders being primarily rhetorical. Shareholder value was here a concept to measure performance on financial markets, not a norm for prioritising shareholders per se. This is why the architects of shareholder 
value distanced themselves from agency theory, at least in the form developed by Michael Jensen, since they rejected its initial assumption that there was an agency problem leading to a lack of managerial accountability (Stern and Willets, 2014; Rappaport 1989)

This process of translation has been a difficult one which is still ongoing. In that respect, the legacy of financialised management is a complex one that cannot be adequately summarised here. We wish, however, to draw attention to the fact that financialised management along with growing capacities for placement of financial securities has profoundly impacted the rules of corporate competition. The problem does not stem simply from a new environment that is geared towards rewarding managers who maximise short-term earnings, but from the new challenges that are posed by a financialised economy in which the ability to capitalise on financial markets can often prove decisive in corporate contests, a fact strongly impressed on the European corporate establishment by the takeover of Mannesmann by Vodafone (Höpner and Jackson, 2006). Having witnessed the financial capacities built by the conglomerates, corporate raiders and LBO firms, it became impossible to ignore the new possibilities for capitalising on financial markets, especially when the compensation of managers itself could be so drastically improved (Krier, 2005). In the process, corporate success became increasingly associated with the ability of firms to position themselves on financial markets. This, of course, often meant the ability of managers to speak to shareholder interest. But as in the case of Litton and LTV, this did not necessarily mean serving them. That shareholders largely benefitted from managerial dealings may be clear, but we should not interpret this as being dictated by shareholders. If anything, it was the interests of shareholders that were aligned with those of financialised management, not the other way around.

We thus come back to Zysman's initial concern with 'patience' as a problem of power, one concerned with disciplining the decision-makers which are shaping the future of corporations: the managers. For in emphasising the challenges faced by managers through this process of financialisation and their agency in responding to them, we argue that short termism may be more deeply entrenched than sometimes believed. The problem is not simply one of containing managerial excesses or shielding managers from market pressures. It involves dealing with the very capacities that financialised managers have built, and come to depend upon, in the form of financialised management.

\section{Conclusion: patient capital after shareholder value}

This article has challenged the literature about patient capital for its tendency to exaggerate the agency of financiers versus that of managers. It argues that one should not simply focus on the sources of capital but analyse this in relation to how this capital is being used. In other words, patient capital has to be analysed explicitly as a social relation; one which involves managers and financiers. By tracing the lineages of financialised management back to the 1950s and 1960s, we have used history to highlight the agency of management in the rise of financialised management. As we argued, financialised conglomerates rode financial markets to spectacular successes in terms of fast corporate growth. By using financial markets as a baseline for strategy, they placed great emphasis on financial transactions as the engine for corporate growth. In doing so, they developed many of the key ideas which came to be later associated with managerial strategies during the era of shareholder value.

This historical perspective suggests that the turn of NFCs towards financialisation may be more profound and damaging than what is commonly recognised in the patient capital literature. In an age where capital can be mobilised with ease and on an astonishing scale (see the 2013 \$49 billion bond issue by Verizon), it is often dangerous for managers to focus mostly on improving productive efficiency when competitors are taking strong positions on financial markets from which they can launch takeovers. The financial muscle provided by securitisation has transformed the parameters of corporate competition. For it is not simply a pattern of re-distribution imposed by shareholders that is at stake, but the re-shaping of competitive incentives under financialisation. 
Contrary to the assumption that the problem for corporations is the lack of financial support for patient strategies, the problem may in fact have to do with there being too much financing available to corporations. This has made it more advantageous to pursue financialised strategies of growth through capture (despite limited success in terms of profitability), rather than traditional strategies of investment. The challenge then is not simply to replace certain types of financiers with others in order to free managers from the concerns of shareholders. It may have more to do with limiting the possibilities for firms to capitalise on financial markets.

This highlights a danger for the literature on patient capital which has been driven by a laudable intent to provide space for, and encourage, more long-term managerial strategies that serve a broader range of stakeholders too often neglected under the era of shareholder value. For in focusing on the sources of capital, those who champion patient capital may unwittingly serve the interests of management. The challenge we argue is not foremost to secure stable financial resources for management, but to address financialised management itself. In other words, the problem does not lie mainly on the side of lenders. It concerns the very nature of managerialism in a financialised world.

\section{References}

Armour, J. and Cheffins, B. (2014) 'Origins of the Market for Corporate Control', University of Illinois Law Review, pp. 1835-1866.

Aspara, J., Panjuen, K., Tikkanen, H, and Tainio, R. (2014) 'Explaining Corporate Short-Termism: Self-Reinforcing Processes and Biases among investors, the media and corporate managers', SocioEconomic Review, 12: 667-693

Aspen Institute (2009) Overcoming Short-termism: A Call for a More Responsible Approach to Investment and Business Management, accessed at https://www.aspeninstitute.org/sites/default/files/content/docs/pubs/overcome_short_state0909_0.p df on April 24, 2016.

Bailey J. and Godsall, J. (2013) 'Short-termism: Insights from Business Leaders Findings from a Global Survey of Business Leaders', commissioned by McKinsey \& Company and CPP Investment Board, accessed at: http://www.shareholderforum.com/access/Library/20131226_McKinsey.pdf on February 11, 2016.

Bartlett, S. (1991) The Money Machine: How KKR Manufactured Power \& Profits, New York, Warner Books.

Baskin, J. B. and Miranti, P. J. (1997) A History of Corporate Finance, New York, Cambridge University Press.

Berg, N. (1969) 'What is Different About Conglomerate Management', Harvard Business Review, 47: 112-120.

Briloff, A. (1970) 'Accounting Practices and the Merger Movement', Notre Dame Law Review, 45 (4): 604-628.

Brooks, J. (1973) The Go-Go Years, New York, Weybright and Talley.

Bruck, C. (1989) The Predator's Ball: The Inside Story of Drexel Burnham and the Rise of Junk Bond Raiders, London, Penguin. 
Chandler, A. (1990) Scale and Scope: The Dynamics of Industrial Capitalism, London, Harvard University Press.

Chernow, R. (1990) The House of Morgans: An American Banking Dynasty and the Rise of Modern Finance, New York, Touchstone.

Cole, B. (2008) M\&A Titans: The Pioneers who Shaped Wall Street's Mergers and Acquisitions Industry, Hoboken (NJ), John Wiley \& Sons.

Davis. G, Diekmann, K. and Tinsley, C. (1994) 'The Decline and Fall of the Conglomerate Firm in the 1980s: The Deinstitutionalization of an Organizational Form', American Sociological Review, 59 (4): 547-570.

Deeg, R. and Hardie, H. (2016) 'What is patient capital and who supplies it?', Socio-Economic Review, This issue.

Duménil, G. and Lévy, D. (2004) Capital Resurgent: Roots of the Neoliberal Revolution, London, Harvard University Press.

Fligstein, N. (1990) The Transformation of Corporate Control, London, Harvard University Press.

Fligstein, N. and Markowitz, L. (1993) 'Financial Reorganization of American Corporations in the 1980s', in Wilson, W. J. (ed.), Sociology and the Public Agenda, Newbury Park, CA, Sage, pp. 185-206.

Frey, D. (1986) 'The US needs patient investors', Fortune, 114, 125.

Froud, J., Johal, S., Leaver, A., and Williams, K. (2006) Financialization and Strategy: Narrative and Numbers, London, Routledge.

Gaughan, P. (2011) Mergers, Acquisitions and Corporate Restructurings, John Wiley \& Sons, Hoboken (NJ).

Gerschenkron, A. (1962) Economic Backwardness in Historical Perspective, Cambridge, Mass., Harvard University Press.

Gillan, S. L., and Starks, L. T. (2007) 'The Evolution of Shareholder Activism in the United States', Journal of Applied Corporate Finance, 19 (1), pp. 55-73.

Goolrick, R. (1978) Public Policy toward Corporate Growth: The ITT Merger Cases, London, Kennikat Press.

Grieman, G. (1970) 'Mergers', Notre Dame Law Review, 45, pp. 698-745.

Haldane, A. (2015) 'Fast Finance and Slow Growth', In Mazzucato, M. and Penna, C. (eds.), Mission-Oriented Finance for Innovation: New Ideas for Investment-Led Growth, Lanham, MD, Policy Network, pp. 13-20.

Ho, K. (2009) Liquidated: An Ethnography of Wall Street, London, Duke University Press.

Höpner, M. and G. Jackson (2006) 'Revisiting the Mannesmann Takeover: how Markets for 
Corporate Control Emerge', European Management Review, 3(3), pp. 142-155.

Horn, L. (2011) 'How did we end up here? The rise of shareholder value in EU corporate governance regulation', In Vitols S. and Kluge, N. (eds.), The Sustainable Company: a new approach to corporate governance, European Trade Union Institute (ETUI), Brussels, pp. 39-58

Hyman, L. (2012) 'Rethinking the Postwar Corporation: Management, Monopolies, and Markets', In Phillips-Fein, K. and Zelizer, J. (eds.), What's Good for Business: Business and Politics Since World War II, Oxford, Oxford University Press, pp. 195-212.

Jackson, G. and A. Petraki (2011) 'How does corporate governance lead to short-termism?', in Vitols S. and Kluge N. (eds) The Sustainable Company: a new approach to corporate governance, European Trade Union Institute (ETUI), Brussels, pp. 199-226.

Johnson, E. (1990) ‘An Insider’s Call for Outside Direction', Harvard Business Review, 68 (2), pp. 46-56.

Kaufman, A., and Englander, E. J. (1993) 'Kohlberg Kravis Roberts \& Co. And the Restructuring of American Capitalism', Business History Review, 67, pp. 52-97.

Kay, J. (2012) 'The Kay Review of UK Equity Markets and Long-Term Decision Making', accessed at https://www.gov.uk/government/uploads/system/uploads/attachment_data/file/253454/bis-12-917kay-review-of-equity-markets-final-report.pdf on January 21, 2016.

Kiechel III, W. (2010) The Lords of Strategy: The Secret Intellectual History of the New Corporate World, Boston, Harvard Business Press.

Knafo, S. (2013) The Making of Modern Finance: Liberal Governance and the Gold Standard. New York, Routledge.

Krier, D. (2005) Speculative Management: Stock Market Power and Corporate Change, Albany, State of New York University Press.

Laverty K. (1996) 'Economic "Short-Termism": The Debate, the Unresolved Issues, and the Implications for Management Practice and Research', Academic Management Review, 21 (3) 825860.

Lazonick, W., and O'Sullivan, M. (1997) 'Finance and Industrial Development. Part I: The United States and the United Kingdom', Financial History Review, 4 (1), pp. 7-29.

Lazonick, W., and O'Sullivan, M. (2000) 'Maximizing Shareholder Value: A New Ideology for Corporate Governance', Economy and Society, 29 (1), pp. 13-35.

Lundine, S. (1983) 'Now Is the Time for a National Industrial Strategy', Challenge, 26 (3), pp. 1621.

Madrick J. (1987) Taking America: How we got from the First Hostile Takeover to Megamergers, Corporate raiding and Scandal, London, Bantam Books.

O'sullivan, M. (2000) Contests for Corporate Control: Corporate Governance and Economic Performance in the United States and Germany, Oxford, Oxford University Press. 
Ott, J. (2011) When Wall Street met Main Street: The Quest for an Investors' Democracy, London, Harvard University Press.

Prechel, H. (1997) 'Corporate Transformation to the Multilayered Subsidiary Form: Changing Economic Conditions and State Business Policy’, Sociological Forum, 12 (3), pp. 405-439.

Rappaport, A. (1979) 'Strategic Analysis for more Profitable Acquisitions', Harvard Business Review, 57 (4), pp. 99-110.

Rappaport, A. (1989) 'The Staying Power of the Public Corporation', Harvard Business Review, 68 (1), pp. 96-104.

Raw, C. (1977) Slater Walker, London, Andre Deutsch Ltd.

Roe, M. (2013) 'Corporate Short-termism-In the Boardroom and in the Courtroom', The Business Lawyer, 68 (4), pp. 977-1006.

Sobel, R. (1984) The Rise and Fall of the Conglomerate Kings, Washington, Beardbooks.

Sobel, R. (1993) Dangerous Dreamers: the Financial Innovators from Charles Merrill to Michael Milken, Washington D.C., Beard Books.

Soener, M. (2015) 'Why do Firms Financialize? Meso-Level Evidence from the US Apparel and Footwear Industry, 1991-2005', Socio-Economic Review, 13 (3), pp. 549-573.

Stern, B. (1992) License to Steal: The Untold Story of Michael Milken and the Conspiracy to Bilk the Nation, New York, Simon \& Schuster.

Stern, J. and Willett, J. T. (2014) 'A Look Back at the Beginnings of EVA and Value-Based Management', Journal of Applied Corporate Finance, 26 (2), pp. 39-46.

Stearns, L. B. and Allan, K. (1996) 'Economic Behavior in Institutional Environments: The Corporate Merger Wave of the 1980s’, American Sociological Review, 61 (4), pp. 699-718.

Van der Zwan, N. (2014) 'Making sense of financialisation', Socio-Economic Review, 12 (1), pp. 99-129.

Wehinger, G (2011) 'Fostering Long-term Investment and Economic Growth: Summary of a HighLevel OECD Financial Roundtable’, OECD Journal: Financial Market Trends, 1, pp. 9-29.

Zey, M. (1993) Banking on fraud: Drexel, Junk Bonds, and Buyouts, New York, Aldine de Gruyter.

Zorn, D. (2004) 'Here a Chief, There a Chief: The Rise of the CFO in the American Firm', American Sociological Review, 69: 345-364.

Zorn, D., Dobbin, F., Dierkes, J. and Man-Shan, K. (2004) 'Managing Investors: How Financial Markets Reshaped the American Firm', In Knorr-Cetina, K. and Prada, A. (eds.), Sociology of Financial Markets, London, Oxford University Press, pp. 269-289.

Zysman, J. (1983) Governments, Markets and Growth: Financial Systems and the Politics of Industrial Change, Ithaca, Cornell University Press. 